\title{
SOME PROBLEMS OF LEGAL ADAPTATION OF UKRAINE IN THE CONDITIONS OF EU INTERNAL MARKET (IN CONTEXT OF AGREEMENT ON ASSOCIATION OF UKRAINE WITH EU)
}

\section{Kharytonov Ye. O.}

\section{INTRODUCTION}

By signing the agreement on association with the EU Ukraine promulgated its objective to become a future member of EU, actually declaring the adoption of European values. In this connection the importance of such factors as the ability of our society to accept European basic civilizational values (liberalism, individualism, human rights, private property, freedom of contract etc.), without which real progress is impossible, increased. After ratification of agreement in September 16, 2014, the process of European integration of Ukraine passed in a practical phase, which in the field of law makes the task of legal adaptation to conditions of the EU internal market.

Although the problems of adaptation of national legal systems in Europe, bringing national legislation in line with European standards have repeatedly been the subject of scientific analysis ${ }^{1}$ many of them remain insufficiently studied. As a consequence scientific researches in this field do not lose their relevance. Thus one of the most important problems of adaptation is a research in the field of private law, a concept of which is an integral part of European civilization, including axiological guidance for those wishing to join the EU. Furthermore, a legal adaptation of "participants" to the terms of the EU internal market should be in this area.

\footnotetext{
1 Сучасні проблеми адаптації цивільного законодавства до стандартів Європейського Союзу : Матеріали I Міжнародної науково-методичної конференції. Львів, 2006. Вип. 1. 514 с.; Проблеми систематизації приватного права України та Європи : моногр. / За заг. ред. Ю.В. Білоусова. К. : Науково-дослідний інститут приватного права і підприємництва АПрНУ, 2009. 204 с.; Грищак С.В. Теоретичні основи адаптації законодавства України до законодавства Європейського Союзу / С.В. Грищак // Форум права. 2012. № 4. С. 273-275; Середа Т.М. Проблеми адаптації законодавства України до законодавства Європейського Союзу [Електронний ресурс] / Т.М. Середа // Юридичний часопис Національної академії внутрішніх справ. 2012. № 1(3). С. 50-56. Режим доступу: http://nbuv.gov.ua/UJRN/aymvs_2012_1(3)_7; Хоменко О.О. Діалог сучасних правових систем. Адаптація правової системи України до європейського права / О.О. Хоменко // Європейські студії і право. 2011. № 3. Режим доступу: http://eurolaw.org.ua/docs/2011_3/txts/13-Homenko.pdf; Сучасні проблеми порівняльного правознавства: зб. наук.праць / за ред. Ю.С. Шемшученка, Я.В. Лазура. ; упор. О.В. Кресін, М.В. Савчин. Ужгород-Київ: "Говерла", 2015. 216 с.
} 
Among the most important issues, which have to be settled in this area, we should clarify: the legal nature of adaptation; the object of this adaptation; conditions and principles of the adaptation.

\section{Algorithm of adaptation of Ukraine to the EU legal system}

It should be noted, that although problems of adaptation of legislation and legal systems in recent years have been the subject of studies of native jurists ${ }^{2}$, the term "adaptation" is still poorly understood and seems to be outside investigation of adaptation. So features and the essence of the concept of "legal adaptation" should be studied in this research.

Getting to the matter, first of all, we have to establish whether the concept of "adaptation of legislation" and "legal adaptation" are identical.

In the practice of national legislative bodies it is traditionally said about "the adaptation of Ukraine's legislation to the legislation of the EU" (Law of Ukraine "On the State Program of Adaptation of Ukraine's legislation to the legislation of the EU" March, 18, 2004 № 1629, Decree of Cabinet of Ministers of Ukraine (October, 15, 2004 № 1365) "Some issues of adaptation of legislation of Ukraine to the legislation of the EU" and others.). This approach is reflected in scientific publications ${ }^{3}$.

But the term "EU legislation" is often expanded, making it identical with the "acquis communautaire", which, including legislative acts, were adopted inside the three pillars of the EU, but is not limited by them. Thus, the Strategy of Ukraine's integration into the European Union states that: "The aim of Adaptation of Ukraine's legislation to legislation of the EU is to get closer to the modern European system of law". Thus, although it is said about the adaptation of "Ukraine's legislation to legislation of the EU", the

${ }^{2}$ Грищак С.В. Теоретичні основи адаптації законодавства України до законодавства Європейського Союзу / С.В. Грищак // Форум права. 2012. № 4. С. 273-275; Середа Т.М. Проблеми адаптації законодавства України до законодавства Європейського Союзу [Електронний ресурс] / Т.М. Середа // Юридичний часопис Національної академії внутрішніх справ. 2012. № 1(3). С. 50-56. Режим доступу: http://nbuv.gov.ua/UJRN/aymvs_2012_1(3)_7; Хоменко О.О. Діалог сучасних правових систем. Адаптація правової системи України до європейського права / О.О. Хоменко // Європейські студії і право. 2011. № 3. Режим доступу: http://eurolaw.org.ua/docs/2011_3/txts/13-Homenko.pdf

${ }^{3}$ Грищак С.В. Теоретичні основи адаптації законодавства України до законодавства Європейського Союзу / С.В. Грищак// Форум права. 2012. № 4. С. 273-275; Середа Т.М. Проблеми адаптації законодавства України до законодавства Європейського Союзу. / T.М. Середа // Юридичний часопис Національної академії внутрішніх справ. 2012. № 1(3). С. 50-56. Режим доступу: http://nbuv.gov.ua/UJRN/aymvs_2012_1(3)_7

4 Петров П.Д. Інституційний механізм адаптації законодавства України до законодавства ЄС. [Електроний ресурс]. - Режим доступу: http://old.minjust.gov.ua/4748

5 Петров П.Д. Інституційний механізм адаптації законодавства України до законодавства ЄС. [Електроний ресурс]. - Режим доступу: http://old.minjust.gov.ua/4748 
adaptation " legislation of Ukraine to the legal system of the EU" is meant. This "extension" creates additional difficulties. Moreover, the terms "law" and "legal system" are used virtually identical".

The situation seems to be a consequence of the fact that positivist, "regulatory" approach still prevails in the characteristics of law in domestic legal doctrine. This approach is a cause why the law is understood as an amount of mandatory rules of law that are reflected and enshrined in legislation. However, the ensuring of functioning of a society as a complex dynamic system is just one of the areas of legal regulation. But law, as a phenomenon of civilization, is also intended to be a carrier of higher principles, fundamental values of civilization, which have to realize the historical destiny of the society related with the statement in it the forces of reason, high humanitarian principles.

Thus, the law not only reflects the demands of civilization by giving legal view and realization of them, but also serves as a factor of expression of person, his or her creativity and self-development ${ }^{7}$. Thus the law can be defined as a civilization category, which simultaneously serves as an element of social and political order and an element of social consciousness, which is part of the human mind and its outlook, reflecting the idea of individuals and the society of justice, goodness, humanity and so on. This allows us to consider the law in general, and private law, in particular, as a concept (conceptus. lat. - thought, idea, definition), which is understood here as a set of ideas expressed verbally about a social phenomenon. The definition of the concept is aimed at transmitting the meaning of a word, which this concept affects in accordance with the elements that make up this concept ${ }^{8}$.

It can be concluded, when understanding the law in this way and considering it as a part of a legal system, that legal adaptation is not limited only to harmonization "of the legislation of Ukraine to the legislation of the EU", and is inherently more complex and therefore it must be considered as the adaptation of the domestic concept of law to the concept of the European law in general, and private law in particular.

Legal adaptation is a form of interaction of legal systems, type of "legal acculturation", which is understood as a process of mutual influence and as the result of the influence of cultures on each other, borrowing the phenomenon from one environment and implementation of it in a different environment, the process of borrowing, implemented in the assimilation of innovations by the

\footnotetext{
${ }^{6}$ Хоменко О.О. Діалог сучасних правових систем. Адаптація правової системи України до Європейського права. // http://eurolaw.org.ua/docs/2011_3/txts/13-Homenko.pdf

7 Алексеев С.С. Право : азбука - теория - философия : Опыт комплексного исследования / С.С. Алексеев. М. : Статут, 1999. С. 200, 219, 221, 224.

${ }^{8}$ Бержель Ж.-Л. Общая теория права / Пер.с фр. М., 2000. С. 342
} 
group (person, people) ${ }^{9}$. To be precise, legal acculturation is a universal concept that characterizes it as grafting one legal system to another ${ }^{10}$, any borrowing of some elements in other legal systems (some people prefer the term "legal (juridical) transplantations" ${ }^{\prime 11}$ ). In turn, it can be said about the universal concept of acculturation as following: reception, legal expansion, simple borrowing, adaptation and more. However, we understand legal adaptation as an adaptation of own legal system (its elements) to another similar legal system.

The success of legal adaptation depends on the convergence of legal systems, which determines the necessity of taking into account the properties of the latter that relate to the areas where the adaption takes place. So, it is reasonable to consider the complex of problems associated with the definition of private law, keeping in mind that the latter can be considered both as a sphere and as an object of adaptation.

The category of private law depends on European civilization for its existence and characteristics and, therefore, contains valuable guidance for those wishing to join the EU. At the same time, despite lengthy discussions on the notion and nature of the European law, private law, the influence of these concepts on the legislation of Ukraine, etc., in regard to their characteristics there are numerous differences. It stipulates the need to determine what the law of the EU is and whether the domestic concept of civil rights and legislation are able to adapt to the conditions of the EU internal market, what principles of adaptation are.

While defining the essence of the term and notion of "European law", we believe that they can mean an expressed verbal presentation, rational and emotional perception of human rights as a part of the "European world" (European civilization), where the man exists, feeling himself a part of it, whereas, the designation of the "EU law" is characterized by a set of legal rules, regulations and other legal means (the discussions in the European Parliament regarding the Community legislation and the like), which regulate the processes of European integration and of the EU activity.

The above mentioned is related to the "European law" and "The Law of the European Union" as a whole, but fails to fully account for the features of the "private sphere" of existence of law. Therefore, there is a need to clarify the nature of private law as a phenomenon that defines the legal position of a private individual in a society.

9 Юридическая аккультурация и управление профессиональной юридической деятельностью. Режим доступу: http://advocatkuzmin.ru/ articles/107-article25

${ }^{10}$ Карбонье Ж. Юридическая соціологія : [пер. с франц.] / Пер. и вступит. статья проф. В.А. Туманова. М. : Прогресс, 1986. С. 199.

${ }^{11}$ Watson A. Legal Transplants: An Approach to Comparative Law. / A. Watson. Edinburgh : Scottish Academic Press, 1974. 106 p.; Watson A. Evolution of Western Private Law (Expanded Edition). / A. Watson. - Baltimore, London : Johns Hopkins University Press, 2000. 320 p. 
Before you characterize a civil society, it is worth mentioning about the existence of the position, according to which every social and political system corresponds to a particular basic model of such a society, which in each country is evident in the national and specific form, as universal and purely national cultural and historical elements are involved in the formation of national identity and political culture of the people ${ }^{12}$. However, the presence of "purely national cultural and historical elements" does not mean creating a "special basic model of the civil society". Dealing with such phenomena not only the presence of universal and national and special elements must be taken into account but individual ones ("specific determinative") as well. If the universal applies to all socio-political categories, the individual determines the characteristic of only certain types that may be taken as the basis of other systems (i.e. to serve as the "base" for them), but it does not lose its genetic entity because of that. So it can become the "base" for borrowing and be adapted, but it does not become a "special basis" because of that. There cannot be its "special basic model" in the society where there are no democratic relations and which does not recognize the existence of private relationships. Civil society is a phenomenon (force) that exists in a democracy (democratization space). Such forces as: the political elite; the economic community (the business); the sphere of legislation; the State bureaucracy co-exist with it. The last two components, which are based on the general principles of the system of governinment, are the substance of every modern democratic system. All the rest are certain organizations and groups of people who provide a democratic system of a specific nature. Thus, when economic and political community consists mainly of people involved and of the institutions aiming at gaining power or profit, a civil society is the sphere of action of ordinary people who join forces to express their interests, protect and implement their daily requirements ${ }^{13}$.

The indicated circumstances lead to consideration of civil society through the prism of liberalism and the market ${ }^{14}$. The view from the standpoint of liberalism necessitates consideration of peculiarities of human component of a civil society ${ }^{15}$. This refers to the type of a person that was formed on the

12 Требін М. Західна модель громадянського суспільства: концептуальний підхід / М. Требін // Гілея : науковий вісник. 2013. № 75. С. 253.

13 Ховард М. Слабость гражданского общества в посткоммунистической Европе / пер. с англ. И.Е. Кокарева. М. : Аспект-Пресс, 2009. С. 49-51.

14 Джин Л. Коэн, Эндрю Арато Гражданское общество и политическая теория : [пер. с англ.] / Общ. ред. И.И. Мюрберг. - М. : Весь Мир, 2003. С. 7.

15 Сучасна правова енциклопедія / О.В. Зайчук, О.Л. Копиленко, Н.М. Оніщенко [та ін.]; за аг ред. О.В. Зайчука; Ін-т законодавства Верхов. Ради України. - К. : Юрінком Інтер, 2009. - С. 80; Біленчук П.Д., Гвоздецький В.Д., Сливка С.С. Філософія права : навч. посібн. / За ред. П.Д. Біленчука. К. : Атіка, 1999. С. 57. 
ground of division of labor because of its regulator - the market ${ }^{16}$. E. Gellner proposed the category of a "modular man", the implementation of which allows to accentuate, that the establishment of civil society provides unique opportunities to achieve individualization and simultaneous creation of political associations that balance the state, but do not enslave its members. The emergence of a modular man made possible the emergence of a civil society ${ }^{17}$. The market causes the appearance of a modular man, and a set of modular individuals creates a civil society. A civil society, as a certain kind of social reflection of the market system, "recodes" the imperatives of the market into formulae of freedom, and formulae of freedom are ionscribed into social imperatives of democracy. Its main lever of coordination of demand and supply diversity, pluralism of views and positions, bringing them into the system unity (equilibrium), is harmony (social contract) $)^{18}$.

Assessing a civil society as a product of harmonization of interests and relations between private individuals acting in market conditions, as its characteristic features, may be considered the fact, that it: 1) appears as a the result of agreement between private parties that correspond the notion of a "modular man", 2) has liberalism as its basis, 3) exists in the conditions of a developed market, 4) apprehends the formula of freedom as social imperatives of democracy, 5) has human relationships, activity of democratic and liberal character as foundation, 6) is regarded primarily as a behavioral and institutional phenomenon (as opposed to "social capital") 19 . The state does not control a civil society, but if it is a rule-of-law state, it must secure conditions for its functioning and life activity ${ }^{20}$, as the principle of priority functioning of a civil society regarding state power becomes more and more typical for the general dynamics of development of contemporary world civilization ${ }^{21}$. This separates a civil society from both the state and the economic structures that

${ }^{16}$ Сміт Адам. Добробут націй: Дослідження про природу та причини добробуту націй / пер. $з$ англ. О.Васильєва, М. Межевікіної, А. Малівського. наук. ред. Є. Литвин. К. : PortRoyal, 2001. C. 11-15.

${ }^{17}$ Геллнер Э. Условия свободы. Гражданское общество и его исторические соперники / Э. Геллнер. М. : Московская школа политических исследований, 2004. С. 118-120.

18 Пасько I.T. Громадянське суспільство і національна ідея. (Україна на тлі європейських процесів. Компаративні нариси) / І.Т. Пасько, Я.І. Пасько. Донецьк : ЦГО НАН України, УКЦентр, 1999. С. 52-55.

${ }^{19}$ Ховард М. Слабость гражданского общества в посткоммунистической Европе / пер.с англ. И.Е. Кокарева. М. : Аспект-Пресс, 2009. С. 57.

20 Кузнєцова Н. Громадянське суспільство, держава, приватне право : проблеми співвідношення та взаємодії / Н. Кузнєцова // Право України. 2014. № 4. С. 66.

${ }^{21}$ Оніщенко Н. До питання про пошук балансу у співвідношенні громадянського суспільства та держави: теоретико-методологічні аспекти / Н. Оніщенко // Право України. 2014. № 4. С. 55; Колодій А. Громадянське суспільство: ознаки, структурні елементи, співвідношення із державою / А. Колодій // Право України. 2014. № 4. С. 9-12. 
allows it not only to play the role of opposition in terms of authoritarian regimes, but also revive its critical potential in terms of liberal democracy ${ }^{22}$. In this case rigid "binding" of concepts "civil society" and "state" to one another disappears, and thus there is the capacity to consider the latter as a variable component that promotes or hinders the development of a civil society.

In determining the nature of adaptation to these principles of functioning of the sphere of private law, the problem of methodological character arises, due to the fact that the interaction of a state with a civil society to a great extent is provided through public law, rather than private law. As a civil society alone can not cope with the conflicts of the variety of interests of people and their groups to reconcile the unmatched interests, etc., for this purpose the state is formed by establishing legal connections and relationships that create control structures and determine the procedure of their activity and cooperation. Public authority should create optimal conditions for the normal functioning of a civil society, protect it, promote conflict resolution. The basis of their relationship is ideology that could be called "person-centered" 23 and that is reflected in the metaphorical characterization: "Democratic state power - a "night watchman" in building "of the person that self-perfects". It is an effective and active textbook of freedom, physical and spiritual beauty of a person $^{24}$. The indicated concerns the security of both human rights and freedoms and the functioning of the market, that is the correlation of a civil society and private law, making people truly free, giving everyone the opportunity to choose their purpose ${ }^{25}$. At the first government encroachment on the economic freedom all the political and legal freedoms turn into deceit $^{26}$.

Adaption to the conditions of the EU internal market, which lives by the rules laid down, requires clear understanding of the existence of the general problem of choice between a private law (humanitarian) approach and a public law approach (state-regulatory). The prospect of choice is that the replacement of the market with the planned economy takes away freedom and

${ }^{22}$ Джин Л. Коэн, Эндрю Арато Гражданское общество и политическая теория : [пер. с англ.] / Общ. ред. И.И. Мюрберг. М. : Весь Мир, 2003. С. 7.

23 Лотюк О.С. До питання співвідношення громадянського суспільства і держави / О.С. Лотюк // Часопис Київського ун-ту права. 2014. № 2. С. 80.

${ }^{24}$ Оніщенко Н.М. До питання про відповідальність держави перед громадянським суспільством / Н.М. Оніщенко, С.В. Стоєцький, С.О. Сунєгін // Часопис Київського ун-ту права. 2014. № 2. С. 11.

${ }^{25}$ Фридрих А. фон Хайек. Познание, конкуренция и свобода / А. фон Хайек Фридрих. СПб. : ПНЕВМА 1999. С. 58.

26 Людвиг фон Мизес Индивид, рынок и правовое государство (антология работ Л. Мизеса) / под ред. Д. Антисери и М. Балдини. СПб. : Пнема, 1999. С. 129. 
leaves only the right to obey. For this option is unacceptable, we must recognize that the state serves as a regulator "on request concerning all the concepts described above." The above mentioned concepts are correlates that complement each other in a democratic society, mediating such areas as: socio-political (civil society), economic (market), legal (private law).

These circumstances should be taken into account when determining the algorithm of adaptation of Ukraine to the EU legal system (at the present stage it looks like legal adaptation to the conditions of the EU internal market, which lies primarily in the perception and acceptance of the concept of private law). Meanwhile the problems of ideological, mental compatibility, etc. should be solved, without which the desired result of adaptation of consciousness, legal thinking, legal doctrine, legislation and finally the concept of law (in particular, private law) can not be achieved.

\section{Domestic experience in adapting to European values}

The subject matter of the article can not dwell on these matters in detail, but still the brightest areas of such adaptation are worth mentioning. As the first of these "civilizational compatibility" is to be mentioned because it affects the ability to adapt to European values in general and to the field of private law in particular.

Therefore it is necessary once again to refer to civilizational dominants of Ukraine, peculiarities of the formation of which are related to the fact that in the course of most of its history it was situated on the verge of "East - West", being a typical country of Uniate traditions according to its character, while being a reflection facilitated by the lack of territorial cohesion in the World outlook.

The dominant ideas were greatly influenced by the peculiar features of the Ukrainian national mentality ${ }^{27}$, which was formed on the ground of close interaction of three cultures - ancient, Scythian-Sarmatian and Slavonic ${ }^{28}$. Their archetypes were perceived mentally from Kievan Rus. They also added Scandinavian features over time ${ }^{29}$ The mentality algorithm of Kyivan Rus was significantly affected by the acceptance of Christianity in its Byzantine option. However, the people officially taking the Byzantine orthodoxy have retained

27 Смітюх Г.Є. Україна сакральна : минуле, сьогодення, майбутнє / Г.Є. Смітюх, В.В. Стрілецький. Київ : Знання України, 2006 р. 36 с.

${ }^{28}$ Стражний О.С. Український менталітет. Ілюзії. Міфи. Реальність / О.С. Стражний. К. : Книга, 2008. С. 44-46, 95, 77, 89-90; С. 127-130, 168; С. 172.

${ }^{29}$ Стражний О.С. Український менталітет. Ілюзії. Міфи. Реальність / О.С. Стражний. К. : Книга, 2008. С. 44-46, 95, 77, 89-90; С. 127-130, 168; С. 172. 
mental archetypes of previous generations and gave it to their descendants ${ }^{30}$. A significant degree of distinctive mentality of Ukraine from Byzantine mentality and Western permanent reflections are due to this occasion. Although the mentality of Kyivan Rus was different from Western European mentality of early Middle Ages, it did not accept Byzantine mentality in the full scope either, assuming the character of the original and fairly contradictory. The drift toward the "Byzantines" was prevented by the TatarMongol invasion, which was accompanied by the growing power and expansion of Muscovy largely due to the Kievan Rus. This caused a natural resistance of ethnic groups living on its territory, and therefore their consolidation (particularly mental) in the process of opposing to the expansion.

At the beginning of the sixteenth century, the events clearly aimed at reapprochingt with the West were taking the place in the cultural field. In 1632 Kyiv Mohyla Collegium, which became the first Ukrainian university, where young people from Ukraine and other countries received education in the European standard, was created. However, the position of the Academy, as the opponent of Catholicism, contributed to the development of its ties with German culture. ${ }^{31}$ However, cultural ties with Protestants did not mean the termination of contacts with Polish Catholics. Therefore, we can not consider a simplified approach to the influence of Poland and attitude to $\mathrm{it}^{32}$. It would be wrong to consider the confessional disputes as a confrontation between the West and East of Ukraine, based on the fact that the Polonization entailed catholization and geographical proximity to Russia helped to strengthen Orthodoxy. Or rather we will say that throughout Ukraine there was a weave of western and eastern Christian traditions in one or another their manifestations. With such civilizational achievements and the desire not to lose cultural contacts with the West (and inherent not only the West but also lands near the Dnieper) Ukraine entered the New time.

Overall, at the end of XVIII and the beginning of XIX century, the national revival happend on Ukrainian territories (in both western and eastern parts). In XIX century, the democratic and antimonarchical movements were developing spreading liberal socialist doctrine. At that time, works by Taras Shevchenko, Ivan Franko, Lesia Ukrainian and other writers, scientists and public figures were characterized by using the antique motives of Ancient Greek and Roman philosophy, research and study of natural rights of a person, justice, fate and

\footnotetext{
${ }^{30}$ Стражний О.С. Український менталітет. Ілюзії. Міфи. Реальність / О.С. Стражний. К. : Книга, 2008. С. 44-46, 95, 77, 89-90; С. 127-130, 168; С. 172.

${ }^{31}$ Нічик В.М. Києво-Могилянська академія і німецька культура / В.М. Нічик. К. : Укр. Центр духовн. культури, 2001. С. 56.

${ }^{32}$ Рябчук М. Польща, польський, поляки / М. Рябчук // Сучасність. 1998. № 11. С. 138-147.
} 
deprivation. The basis of the political and legal views of many prominent thinkers of Ukraine of the time, such as M. Drahomanov, was human rights, freedom and free development, autonomy of the individual. Thus Drahomanov had the history of Ancient Rome as the basis for the study of these issues.

However, the realization that a real chance to preserve the unity of the society and the state was a union was gradually emerging. When not biased, it is difficult to deny that each of them (Krevska, Ostrivska, VilenskoRadomska, Horodelska, Cracowsko-Vilenska, Melnitska, Lublinska, Brestska, Hadiachska) had its positive features and often provoked opposition of not only the representatives of the orthodox community, but magnates, who were dissatisfied with their being removed from the issues of redistribution of power $^{33}$. Eventually, instead of merging a split took place by the confessions: on the one hand - Orthodox magnates, the majority of the clergy and popular masses (impressive unity of popular masses and oligarchs), on the other hand - former hierarchy who supported the king and their supporters, who understood the need for the Union. The attempts to unite Christian churches ended with their crushing, because then instead of two churches, the three churches emerged: the catholic, the orthodox and the Uniate (Greek Catholic).

The situation, that developed, affected the Ukrainian legal system, which had undergone influence both of West and East. However, despite the shortsighted political decisions which led to the loss of statehood, the legal tradition relied essentially on the oriental influence.

After the accession of Ukraine to the Moscow State according to March Articles Hetman territory was not supposed to apply Moscow's legislation, and "ex rights": customary law, Polish-Lithuanian legislation and Magdeburg Law were expected to be kept valid. In preparing the assembly "Rights, by which malorossiysky people are to litigate" (1743) its drafters used the Roman and Germanic sources, Statutes of the Grand Duchy of Lithuania, Polish legislation, customary law and judicial practice of Ukraine ${ }^{34}$. The trend persisted in the preparation of "Collection of Ruthenia rights in 1807" (first draft Civil Code), which contained more borrowings from the Western law.

\footnotetext{
${ }^{33}$ Унія і уніати в польській і слов'янській культурах : Матеріали Краківської міжнародної наукової конференції (17-19 грудня 1992 р.) // Слово і час. 1993. № 3. С. 57; Паславський I. Берестейська унія і українська християнська традиція. Львів: Вид-во Отців Василіян "Мiсiонер", 1997. Паславський I. Берестейська унія і українська християнська традиція / I. Паславський. Львів : Отців Василіян “Місіонер”, 1997. 64 с.; Гадяцький трактат [перкл. 3 польськ.] / В. Шевчука. К. : Записки Наукового товариства імені Т. Шевченка. Т. 89. Львів, 1909. Режим доступу: http://movahistory.org.ua/wiki/Гадяцький трактат.

${ }^{34}$ Права, за якими судиться малоросійський народ. 1743 / НАН України, Інститут держави і права ім. В.М. Корецького, Інститут української археографії та джерелознавства ім. М.С. Грушевського ; упоряд. К.А. Вислобоков ; відп. ред. та авт. передм. Ю.С. Шемшученко. К. : [б.в.], 1997. 547 с.
} 
Besides 515 of references to the Statut of the Grand Duchy of Lithuania, there were 457 references to the "Saxon Svichado (Mirror)", 224 - to the right of Kholmsk, 58 to Magdeburg Law. Thus, the basis of this bill was the Lithuanian, German and Polish right. As for the territories of Ukraine, that were under the power of Austro-Hungary, Poland, Romania etc., there acted laws of that state which was formed within the Western tradition of law.

On such background the formation of principles of concept of private law was carried out on Ukrainian territories, which began in XIX century, foremost, in their Western part. In spite of powerful influence of German jurisprudence the Western tradition of private law in the reception of Ukraine looked, foremost, as an Austrian civil doctrine. In its interpretation O.M. Ogonovskiy, who aimed at an adaptation of Austrian civil doctrine to Ukrainian legal comprehension played a considerable role for Ukraine. ${ }^{35}$ S.S. Dnistryanskiy created the scientific works in the sphere of civil law and on materials of Austrian legislation ${ }^{36}$.

On the whole, Western Ukrainian tradition of private law did not create an original legal conception in this industry and the development of this conception took place in the general mainstream of legal researches of that time. Consequently, Western Ukrainian concept of private (civil) law was formed in the general context of the development of Western tradition of private law, being historically and genetically related to the last.

Referring to the Ukrainian territories which became part of the Russian empire, the adaptation to the Western law there was sometimes actual in the connection with the attempts of the mother country to adapt oneself to the European values and legal achievements in the second half of XIX century. Such attempts were halted by the events of 1917, after which the soviet power began actively to destroy the legal system which had existed before. However, it did not avoid the attempts of the "limited" adaptation (borrowings). In particular, such attempts took place in the first codification of soviet civil legislation, when borrowing from the legislation of the European countries really took place.

Hereupon, the Civil code of RSFSR, adopted on October, 31 in $1922^{37}$ (that served as a standard for CC of Ukraine), imitated German CC (BGB), in

${ }^{35}$ Огоновський О. Система Австрійського права приватного / О. Огоновський. Львів : Науки загальні і право річеве, 1897. 336 с.

36 Дністрянський С. Причинки до реформи приватного права в Австрії / С. Дністрянський // Часопись правнича і економічна. Львів, 1912. Р. 7. Т. 10. С. 1-111; Цивільне право [Текст] : пер. С. Дністрянського. Відень, 1919. Т. 1. 1063 с.; Коваль А. Засадничі погляди Станіслава Дністрянського на основи права та держави / А. Коваль // Вісн. Львів. ун-ту. Сер. юридична. 2012. Вип. 55. С. 74-78.

37 Братусь С.Н. Становление гражданско-правовой концепции регулирования имущественных отношений между социалистическими предприятиями в период НЕПа / С.Н. Братусь // Сов. государство и право. 1987. № 11. С. 51. 
its structure, many legal decisions and others like that. As P.I. Stuchka admited: "According to its essence our Civil code does not differ from those forms of bourgeois civil law, which repeat the formulas of the Roman law on the whole and were created about two millenniums ago" 38 .

The most interesting thing in the soviet experience is that it confirmed not only the possibility of borrowing from the legislation of other countries, which was based on other conceptual basis, but also the flimsiness of such borrowings. An exception was the cases, when they referred to property relations (for example, inheritance) which arose out of the field of ideological battles. However, it is necessary to notice that in this case (as well as the later one, at the attempt of adaptation to "common to all mankind values", "to the mechanisms of progress" 39 during Perestroika), Ukraine, without regard to active scientific researches of its scholars, came forward not as a subject of adaptation, but as a user of already prepared (prepared in the USSR) product. Therefore, Ukraine's own experience of legal adaptation was gained after the proclamation of its independence.

At that time the civil relations were regulated by the legislative acts of former Soviet Union, and also by the majority of acts of the URSR, that continued to operate in that part which did not conflict with the legislation of Ukraine. At the beginning of the 90s of XIX century a significant amount of legislative acts were accepted in Ukraine, conceptual basis of which was an aspiration of the legal providing of sovereignty of a person, equalization of legal position of a person and the state, and others like that. Evidently, the lack of lawmaking of that time was largely due to its unsystematic character. Thus, the development of the concept of civil legislation of Ukraine began, basing on the European concept of law that was based on the ideas of civil society and the rule of $\operatorname{law}^{40}$. However, researches forecast the harmonization of Ukrainian legislation with the European one as a long and complex process. Due to the adoption of some provisions of the Commercial Code and the Family Code the Civil concept as a single Code of private law suffered some losses.

Although these losses were felt, the core of the Civil Code of Ukraine as "passionate" in essence (i.e, one that was created for the future, on a modern conceptual framework as a code of civil society, rule of law and the code of private law, with current European trends and experiences) gives reason to

38 Стучка П.И. Социалистическое хозяйство и советское право / П.И. Стучка // Революция права. 1927. № 1. С. 10-11.

${ }^{39}$ Бутенко А.П. Идти назад - к механизмам прогресса / А.П. Бутенко // Государство и право. 1992. № 4. С. 78.

${ }^{40}$ Кодифікація приватного (цивільного) права України / за ред. А. Довгерта. К. : Укр. центр правн. студій, 2000. 336 с. 
believe that the losses in question can be eliminated in the process of legal approximation of Ukraine to the terms of the EU internal market.

In choosing the destinations for such adaptation, the Draft Common Frame of Reference (DCFR) - Research "Project general reference scheme" "Principles, Definitions and Model Rules of European Private Law"41, should serve as guidelines by which it is planned to solve a number of methodological issues. Central to the idea of DCFR is the rejection of direct regulation of relations in the private-sector. Instead, DCFR is seen as a project that could provide ideas of European private law to a new ground by increasing mutual understanding and promoting collective discussion of problems of private law in Europe ${ }^{42}$.

\section{CONCLUSIONS}

The major problem associated with the adaptation of Ukraine to the terms of the EU internal market is the definition and the legal nature of adaptation. The latter can not be reduced to "legislative approximation", but it is a broader concept, for which all cases of adjustment of its own legal system (cells) to another axiologicaly close legal system should be effectively covered in the process of adaptation of domestic law to the concept of European general concept of law and private law in particular.

Successful adaptation depends on the legal compatibility of legal systems, which leads to the need to consider the properties of the latter, concerning areas of adaptation. In particular, the adaptation in the field of private law should be made taking into account the fact that the latter is a European concept, and therefore involves not only borrowing norms of legislation, but also the values on which the concept of private law correlates with the civil society, developed market and so on.

An essential issue is also establishing principles of adaptation of the national concept of civil law and civil law provisions of Ukraine to principles of European law, since it is on this basis that practically all important adaptation of national legislation to the European concept of law is made.

${ }^{41}$ Principles, Definitions and Model Rules of European Private Law. Draft Common Frame of reference (DCFR). Full Edition. Prepared by the Study Group on a European Civil Code and the Research Group on EC Pri-vate Law (Acquis Group) / Ed. by Christian von Bar and Eric Clive. Vol. I-VI. Munich, 2009.

42 Кристиан фон Бар Предисловие к российскому изданию // Модельные правила европейского частного права. [пер. с англ.] / Кристиан фон Бар, Эрик Клив, Паул Варул ; Науч. ред. Н.Ю. Рассказова. М. : Статут, 2013. С. 23, 25. 


\section{SUMMARY}

The article considers the issues of legal adaptation of the Ukrainian legislation and the domestic legal system to the EU internal market on the basis of the Association Agreement between Ukraine and the EU. Such issues as the nature of legal adaptation of the object, the conditions and principles as well as the concept of this adaptation are considered. The ratio of the concept of adaptation of the right to the concept of law in general and the European private law, in particular, using axiological approach are studied. The defining features of private law, the main correlators, such as civil society and market economy, the methodological basis of private law, which is liberalism, are characterized as well. Answers to the questions such as: Is there a "civilizational compatibility" in these jurisdictions? Is it a problem of Ukrainian mentality to adapt to European values? Does the legal adaptation mean the compatibility of legal systems? What is the role of civil society in the process of European integration (see it through the prism of liberalism and the internal market)? How was the basis of the concept of private law in Ukraine formed in XIX - XXI centuries?

\section{REFERENCES}

1. Сучасні проблеми адаптації цивільного законодавства до стандартів Свропейського Союзу : Матеріали I Міжнародної науковометодичної конференції. - Львів, 2006. - Вип. 1. - 514 с.

2. Проблеми систематизації приватного права України та Європи : моногр. / За заг. ред. Ю.В. Білоусова. - К. : Науково-дослідний інститут приватного права і підприємництва АПрНУ, 2009. - 204 с.

3. Грищак С.В. Теоретичні основи адаптації законодавства України до законодавства Європейського Союзу / С.В. Грищак // Форум права. 2012. - № 4. - С. 273-275.

4. Середа Т.М. Проблеми адаптації законодавства України до законодавства Європейського Союзу [Електронний ресурс] / Т.М. Середа // Юридичний часопис Національної академії внутрішніх справ. - 2012. - № 1(3). - С. 50-56. - Режим доступу: http://nbuv.gov.ua/ UJRN/aymvs_2012_1(3)_7

5. Хоменко О.О. Діалог сучасних правових систем. Адаптація правової системи України до європейського права / О.О. Хоменко // Європейські студії і право. - 2011. - № 3 [Електроний ресурс] - Режим доступу: http://eurolaw.org.ua/docs/2011_3/txts/13-Homenko.pdf

6. Сучасні проблеми порівняльного правознавства: зб. наук.праць / за ред. Ю.С. Шемшученка, Я.В. Лазура. ; упор. О.В. Кресін, М.В. Савчин. - Ужгород-Київ : Говерла, 2015. - 216 с. 
7. Петров П.Д. Інституційний механізм адаптації законодавства України до законодавства ЄС. [Електроний ресурс]. - Режим доступу: http://old.minjust.gov.ua/4748

8. Алексеев С.С. Право : азбука - теория - философия : Опыт комплексного исследования / С.С. Алексеев. - М. : Статут, 1999. - 712 с.

9. Бержель Ж.-Л. Общая теория права / Пер.с фр. - М., 2000. - 576 с.

10. Юридическая аккультурация и управление профессиональной юридической деятельностью. [Електроний ресурс]. - Режим доступу: http:// advocatkuzmin.ru/ articles/107-article25

11. Карбонье Ж. Юридическая соціологія : [пер. с франц.] / Пер. и вступит. статья проф. В.А. Туманова. - М. : Прогресс, 1986. - 352 с.

12. Watson A. Legal Transplants: An Approach to Comparative Law. I A. Watson. - Edinburgh : Scottish Academic Press, 1974. - 106 p.

13. Watson A. Evolution of Western Private Law (Expanded Edition). I A. Watson. - Baltimore, London : Johns Hopkins University Press, 2000. - 320 p.

14. Медушевский А.Н. Российская правовая традиция - опора или преграда? : Доклад и обсуждение / А.Н. Медушевский. - Москва : Фонд “Либеральная Миссия”, 2014. - 136 с.

15. Чичерин Б.Н. Философия права / Б.Н. Чичерин. - СПб. : Наука, 1998. -344 c.

16. Требін М. Західна модель громадянського суспільства: концептуальний підхід / М. Требін // Гілея : науковий вісник. - 2013. № 75. - С. 253-257.

17. Ховард М. Слабость гражданского общества в посткоммунистической Европе / пер.с англ. И.Е. Кокарева. - М. : Аспект-Пресс, 2009. - 192 с.

18. Джин Л. Коэн, Эндрю Арато Гражданское общество и политическая теория : [пер.с англ.] / Общ. ред. И.И. Мюрберг. - М. : Весь Мир, 2003. - 784 с.

19. Сучасна правова енциклопедія / О.В. Зайчук, О.Л. Копиленко, Н.М. Оніщенко [та ін.]; за аг ред. О.В. Зайчука; Ін-т законодавства Верхов. Ради України. - К. : Юрінком Інтер, 2009. - 384 с.

20. Біленчук П.Д., Гвоздецький В.Д., Сливка С.С. Філософія права : навч. посібн. / За ред. П.Д. Біленчука. - К. : Атіка, 1999. - 543 с.

21. Сміт Адам. Добробут націй: Дослідження про природу та причини добробуту націй / пер. 3 англ. О.Васильєва, М. Межевікіної, А. Малівського. наук. ред. Є. Литвин. - К. : Port-Royal, 2001. - 593 с.

22. Геллнер Э. Условия свободы. Гражданское общество и его исторические соперники / Э. Геллнер. - М. : Московская школа политических исследований, 2004. - 240 с.

23. Пасько I.T. Громадянське суспільство і національна ідея. (Україна на тлі європейських процесів. Компаративні нариси) / I.T. Пасько, Я.І. Пасько. - Донецьк : ЦГО НАН України, УКЦентр, 1999. - 184 с. 
24. Кузнєцова Н. Громадянське суспільство, держава, приватне право : проблеми співвідношення та взаємодії / Н. Кузнєцова // Право України. - 2014. - № 4. - С. 63-70.

25. Оніщенко Н. До питання про пошук балансу у співвідношенні громадянського суспільства та держави: теоретико-методологічні аспекти / Н. Оніщенко // Право України. - 2014. - № 4. - С. 55-62.

26. Колодій А. Громадянське суспільство: ознаки, структурні елементи, співвідношення із державою / А. Колодій // Право України. 2014. - № 4. - C. 9-16.

27. Лотюк О.С. До питання співвідношення громадянського суспільства і держави / О.С. Лотюк //Часопис Київського ун-ту права. 2014. - № 2. - C. 338-341.

28. Оніщенко Н.М. До питання про відповідальність держави перед громадянським суспільством / Н.М. Оніщенко, С.В. Стоєцький, С.О. Сунєгін // Часопис Київського ун-ту права. - 2014. - № 2. - С. 9-13.

29. Фридрих А. фон Хайек. Познание, конкуренция и свобода / А. фон Хайек Фридрих. - СПб. : ПНЕВМА 1999. - 288 с.

30. Людвиг фон Мизес Индивид, рынок и правовое государство (антология работ Л. Мизеса) / под ред. Д. Антисери и М. Балдини. СПб. : Пнема, 1999. - 200 с.

31. Смітюх Г.Є. Україна сакральна : минуле, сьогодення, майбутнє / Г.Є. Смітюх, В.В. Стрілецький. - Київ : Знання України, 2006 р. - 36 с.

32. Стражний О.С. Український менталітет. Ілюзії. Міфи. Реальність / О.С. Стражний. - К. : Книга, 2008. - 368 с.

33. Нічик В.М. Києво-Могилянська академія і німецька культура / В.М. Нічик. - К. : Укр. Центр духовн. культури, 2001. - 252 с.

34. Рябчук М. Польща, польський, поляки / М. Рябчук // Сучасність. 1998. - № 11. - С. 138-147.

35. Унія і уніати в польській і слов'янській культурах : Матеріали Краківської міжнародної наукової конференції (17-19 грудня 1992 р.) // Слово і час. - 1993. - № 3. - С. 57-60.

36. Паславський I. Берестейська унія i українська християнська традиція / І. Паславський. - Львів : Отців Василіян “Місіонер”, 1997. - 64 с.

37. Гадяцький трактат [перкл. $з$ польськ.] / В. Шевчука. - К. : Записки Наукового товариства імені Т. Шевченка. - Т. 89. - Львів, 1909. [Електроний ресурс]. - Режим доступу: http://movahistory.org.ua/wiki/ Гадяцький трактат

38. Вулф Ларі Винайдення Східної Европи: Мапа цивілізації у свідомості епохи Просвітництва : [Пер. 3 англ..] / С. Біленького. - К. : Часопис "Критика", 2009. - 592 с.

39. Права, за якими судиться малоросійський народ. 1743 / НАН України, Інститут держави i права ім. В.М.Корецького, Інститут 
української археографії та джерелознавства ім. М.С.Грушевського ; упоряд. К.А. Вислобоков ; відп. ред. та авт. передм. Ю.С. Шемшученко. - К. : [б.в.], 1997. - 547 с.

40. Огоновський О. Система Австрійського права приватного / О. Огоновський. - Львів : Науки загальні і право річеве, 1897. - 336 с.

41. Дністрянський С. Причинки до реформи приватного права в Австрії / С. Дністрянський // Часопись правнича і економічна. - Львів, 1912. - P. 7. -Т. 10. - C. 1-111.

42. Цивільне право / пер. С. Дністрянського. - Відень, 1919. - Т. 1. $1063 \mathrm{c}$.

43. Коваль А. Засадничі погляди Станіслава Дністрянського на основи права та держави / А. Коваль // Вісн. Львів. ун-ту. Сер. юридична. - 2012. - Вип. 55. - С. 74-78.

44.Братусь С.Н. Становление гражданско-правовой концепции регулирования имущественных отношений между социалистическими предприятиями в период НЕПа / С. Н. Братусь // Сов. государство и право. - 1987. - № 11. - С. 50-56.

45. Стучка П.И. Социалистическое хозяйство и советское право / П.И. Стучка // Революция права. - 1927. - № 1. - С. 5-47.

46. Бутенко А. П. Идти назад- к механизмам прогресса / А.П. Бутенко // Государство и право. - 1992. - № 4. - С. 78-84.

47. Кодифікація приватного (цивільного) права України / за ред. А. Довгерта. - К. : Укр. центр правн. студій, 2000. - 336 с.

48. Principles, Definitions and Model Rules of European Private Law. Draft Common Frame of reference (DCFR). Full Edition. Prepared by the Study Group on a European Civil Code and the Research Group on EC Private Law (Acquis Group) / Ed. by Christian von Bar and Eric Clive. Vol. I - VI. Munich, 2009.

49. Кристиан фон Бар Предисловие к российскому изданию // Модельные правила европейского частного права. [пер. с англ.] / Кристиан фон Бар, Эрик Клив, Паул Варул ; Науч. ред. Н.Ю. Рассказова. - М. : Статут, 2013. - 989 с.

Information about the author: Kharytonov Ye. O.,

Doctor of Legal Sciences, Professor, Corresponding Member NAPrN Ukraine,

Head of Department of Civil Law, National University "Odesa Law Academy" 